\title{
The Proprietary Nature of Title-based Financing Interests
}

\author{
MAGDA RACZYNSKA*
}

\section{INTRODUCTION}

The recent work on secured transactions, conducted separately by two expert groups, the Secured Transactions Law Reform Project ${ }^{1}$ and the City of London Law Society ${ }^{2}$, makes it clear there is a case for reform in this area. While a consensus exists in relation to a number of aspects of the future regime, one unresolved debate concerns the legal relationships arising through retention-of-title clauses in contracts of sale, hire-purchase and lease agreements and their variants such as lease-back or buy-back agreements. Their common feature is that an owner of an asset (A) delivers possession of the asset to another - the buyer, lessee or the hirer (B) whilst retaining ownership of the asset. Such relationships are often used functionally as security interests because they enable B to raise finance (typically, to acquire goods on credit) from A while protecting A from the credit risk through the retention of ownership.

The interests created in A through contracts of sale with retention-of-title clauses, hirepurchase and finance lease agreements will be referred to in this chapter as title-based financing interests'. ${ }^{3}$ The functional similarity between such interests and security interests has led to a debate as to whether title-based financing interests ought to be governed by rules similar to those that apply to security interests. ${ }^{4}$ English law has traditionally resisted functionalism in favour of a more conceptual approach. One of the arguments against regulating title-based financing interests in a way similar to security interests is that the former are created through retention of a right $\mathrm{A}$ already has, not a grant of a new property right by $\mathrm{B}$ in favour of A. But this does not say much about nature of A's interest. In discussion on the future of the law, it would be helpful to gain a better understanding of the right that A obtains. This chapter contributes to this understanding. In so doing, it also hopes to cast new light on the list of property rights in English law. While the list may generally be closed (numerus clausus), this papers seeks to make a case, based on the current law, for the recognition of a new type of property right.

The purpose of this chapter is to examine the proprietary nature of title-based financing interests and their place in property law. It explores whether title-based financing interests confer as much protection on the owner as absolute ownership, i.e., whether it is correct to say that A simply retains title to an asset, so no new property right is involved. If a new form of property right is created, which is distinct from ownership, but has not been granted by B to A, it is necessary to consider whether the law regulates it appropriately, taking into account the interests of third parties on whom the right impacts. The chapter does not seek to debate the

\footnotetext{
* Lecturer in Law at University College London. I am grateful for comments received at the Modern Studies in Property Law conference 2018, and for the very helpful suggestions of the editors and anonymous referees.

${ }^{1}$ For the work of the Project, see https://securedtransactionslawreformproject.org (last accessed $27^{\text {th }}$ Septmeber 2018).

${ }^{2}$ See Discussion Draft of the Secured Transactions Code (22/07/2015) available on the pages of the Financial Law Committee of the City of London Law Society, available at http://www.citysolicitors.org.uk (last accessed $27^{\text {th }}$ Septmeber 2018).

${ }^{3}$ Such terminology is also adopted elsewhere (see e.g. H Beale et al, The Law of Security and Title-based Financing (3rd edn, Oxford, Oxford University Press, 2018)) but does not yet seem to be universal.

${ }^{4}$ A number of jurisdictions that have based their regulation of secured transctions on a functional definition of security: see e.g. Article 9 of the Uniform Commercial Code in the USA, New Zealand Personal Property Securities Act 1999; Saskatchewan Personal Property Security Act 1993; the Ontario Personal Property Security Act 1990; in Australia, Personal Property Securities Act 2012 (Cth).
} 
accuracy of the functional approach to title-based interests. ${ }^{5}$ Instead, it seeks to open a wider discussion of whether, from the perspective of property law, title-based financing interests are better understood in a different way than through the prism of ownership, and whether they should be regulated accordingly.

The chapter is structured as follows. First, title-based financing interests are discussed as forms of proprietary disposition, which are different from security interests. The argument made here is that whilst the courts make it clear that title-based financing interests do not constitute grants of a property right by the debtor $(B)$ to the creditor $(\mathrm{A})$, there is nothing to preclude us from regarding A's retention of title as involving the creation of a new right by $A$ herself. Second, it is considered whether A's new right constitutes ownership or a new type of property right, which would have implications for the numerus clausus principle. On the one hand, from A's perspective, based on A's intention relating to the proprietary disposition of the asset, the right that A holds is not new: it is simply ownership. However, as a matter of practice, title-based financing interests give rise to the same types of problems for third parties (e.g. information costs) as property rights lesser in scope than absolute ownership, such as security rights. Furthermore, even under English law, which does not recharacterize title-based interests as security rights, there are important differences between ownership and title-based financing interests, in particular, with respect to damages available for interference with the asset subject to such an interest and to the applicability of exceptions to the nemo dat principle. These factors tend to support the argument that the right that A holds is not ownership but a new type of property right. Third, the chapter looks at the impact of regarding A's right as a new type of property right. This section identifies different responses that could be adopted in law to take into account this new perspective on title-based interests. One response could be to say that since title-based interests are to some extent already different from simple ownership, the law could go further and treat them like security interests by adopting a UCC/PPSA approach. Another is to say that whilst allowing A freedom to retain an interest, English law deals with some of the numerus clausus concerns through other means, such as by limiting the effect on a third party of A's title-based interest. It considers whether the current approach of English law appropriately balances A's interests with those of third parties, and whether it appropriately responds to some of the policy questions around title-based interests.

\section{TITLE-BASED FINANCING INTERESTS AS A FORM OF PROPRIETARY DISPOSITION}

Before we look at the nature of the retained ownership, it is important to consider whether a retention-of-title clause contained in a contract is a result of the exercise of freedom to contract, understood as the freedom to shape rights and obligations arising between the parties, or the freedom of the owner to dispose of its property, governed by property law. If it is the former, it is not generally the case that the law will restrict or regulate that freedom. If the latter, social control seems justifiable to a greater extent, because the imposition of duties and liabilities on third parties needs to be considered, and so the law is more likely to interfere with that freedom. As this section shows, courts will generally give effect to parties' intentions to retain ownership. While the courts have consistently drawn a sharp distinction between title-based financing interests and security interests, there is nothing to suggest that the former could not be a further form of a property right, different from both security interests and ownership.

\footnotetext{
${ }^{5}$ For a critique of functionalism, see M Bridge et al, 'Formalism, Functionalism and Understanding the Law of Secured Transactions' (1999) 44 McGill Law Journal 567.
} 


\section{A. Freedom of contract or freedom to dispose (retain)?}

Consider first a party seeking to purchase goods. That party may obtain credit directly from the supplier in the form of deferment of time of payment of the price for the supplied goods. To reduce the credit risk, the seller may withhold passage of property in the goods until a stipulated condition is fulfilled, typically payment of the price. ${ }^{6}$ The legislative basis for retention of title in the context of sale of goods is s 19(1) of the Sale of Goods Act 1979, which provides that where there is a contract for the sale of specific goods or where goods are subsequently appropriated to the contract, the seller may by the terms of the contract or the appropriation reserve the right of disposal of the goods until certain conditions are fulfilled. ${ }^{7}$ While retention of title is thought to be based on freedom of contract (understood narrowly as freedom to undertake personal obligations) because it often arises on the basis of terms of contract, s 19(1) suggests recognition of a property-based freedom to dispose, which may or may not be exercised at the same time as freedom to contract.

That retention of title is based on a freedom to dispose (including freedom to retain) is further supported by evidence from cases that identify the property-based limits of this freedom. While a contract governing the transaction between A and B can specify the nature of the interest in the asset, and courts will generally give effect to the intentions expressed in the contract, an attempt to extend retention-of-title clause to proceeds and/or products of the goods supplied will not generally be successful. ${ }^{8}$ A "buyer"/ debtor who manufactures a product out of goods supplied becomes the owner of that product (a new thing) through a property doctrine of original (i.e. non-derivative) acquisition of ownership, so the proprietary effect of a clause purporting to retain title is to grant a new proprietary interest in the product in favour of the financier even if the financier sought to "retain" its ownership in the product. 9 The consequences of this are that the new right will be seen as a proprietary right granted by the "buyer"/debtor in favour of the "seller"/creditor by way of security, that is a charge. If the "buyer"/debtor is a company, the charge will be invalid against the liquidator, administrator or creditors unless registered. ${ }^{10}$

The exercise of freedom to dispose (retain) also occurs in hire-purchase and lease agreements. Such agreements in practice usually involve three parties: title to an asset is acquired from the seller by a financier, who then retains it in the contract with the debtor. The debtor under a hire-purchase agreement has an option to purchase the asset at the expiry of a certain period or the completion of a set of payments, whereas the agreement with the financier under a lease contract is so structured that the financier retains property in the goods while the debtor has neither a right nor a power to acquire property in the asset upon payment of the instalments, even if by the end of the payment period the economic value of the asset is negligible so that the financier has no interest in obtaining the asset back.

\footnotetext{
${ }^{6}$ Note that the term "conditional sale" has a specific meaning in the Sale of Goods Act 1979 as an installment sale.

${ }^{7}$ See also Sale of Goods Act 1979, s 17.

${ }^{8}$ Note that following PST Energy 7 Shipping LLC $v$ OW Bunker Malta Ltd [2016] UKSC 23 contracts expressed to be contracts for sale with retention-of-title clauses where on-sale or consumption of goods is envisaged prior to property passing will likely not be classed as contracts of sale of goods.

${ }^{9}$ Clough Mill v Martin [1985] 1 WLR 111 (CA) 120 (Robert Goff LJ) although see more doubtful 124 (Oliver LJ); Borden (UK) Ltd v Scottish Timber Products [1981] Ch 25 (CA). A clause purporting to retain title to proceeds is very likely to amount to a grant of a charge: Re Peachdart [1984]; E Pfeiffer Weinkellerei-

Weineinkauf GmbH v Arbuthnot Factors [1988] 1 WLR 150. See generally M Raczynska, The Law of Tracing in Commercial Transactions (Oxford, Oxford University Press, 2018) ch 5.

${ }^{10}$ Companies Act 2006, s 859H.
} 
It should be added that unlike hire-purchase agreements, leases are not necessarily a financing arrangement. Leases of goods have been recognised in English law from at least as early as 1703 when Lord Holt in Coggs $v$ Barnard ${ }^{11}$, describing various forms of bailment, included delivery of possession of goods to the bailee (B) "to be used by him for hire". ${ }^{12}$ In modern times, delivery of A's goods for B's use in return for rent is very common, as it enables B to gain use of goods for however short or long a term without having to pay the purchase price for them. Typical examples are a holiday rental of a car or the hiring of a construction crane. However, leases have also come to be used precisely so that $\mathrm{B}$ can finance acquisition of asset whilst obtaining use of it. This involves a purchase of the asset by A from a manufacturer or a supplier, and then the grant of a lease of the asset from A to B. Such leases, known as finance leases by contrast to operating leases, ${ }^{13}$ are concluded typically for a period envisaged to cover the working life of the asset at a rental which is calculated to cover the market price of the asset (its capital value) with return on capital. ${ }^{14}$ The development of finance leasing of goods has been fuelled in practice by tax advantages in relation to commercial customers. ${ }^{15}$

A simpler way of expressing the owner's freedom to retain title is to say that it is based on freedom of contract, but one understood broadly as including freedom to retain as well as personal obligations between the parties. The freedom to retain title is particularly wide if one considers that parties may agree that the title will not pass until all debts owed on any account are paid. ${ }^{16}$

\section{B. Title-based financing interests distinguished from security interests}

The courts have consistently maintained that there exists a deep conceptual divide between security interests and title-based financing interests, as this section illustrates. For current puposes, it is particularly important to observe that in drawing this distinction the courts said nothing that would contradict the view, advanced in this chapter, that the retained interest is a new type of property right, different from absolute ownership (and different also from security interests). To show the basis on which the courts have differentiated title-based financing interests from security interests, it is convenient to start by outlining the ways in

\footnotetext{
11 (1703) 2 Ld Raym 909, 92 ER 107; see also M Bridge et al, The Law of Personal Property (2nd edn, London, Sweet \& Maxwell, 2017) para 13-001.

${ }^{12}$ Coggs v Barnard (n 11) 912-3.

${ }^{13}$ The terminology refers to the (now) historical accounting distinction between finance and operating leases whereby in relation to operating leases risks and rewards of the ownership of goods were the lessor's while in the case of finance leases, they were the lessee's: see International Accounting Standards (IAS) 17; Instituted of Chartered Accountants, Statement of Standard Accounting Practice (SSAP) No 21, cited in: Gallagher v Jones (Inspector of Taxes); Threlfall v Jones (Inspector of Taxes) [1994] Ch 107, 117 (Sir Thomas Bingham MR); and in the CA in On Demand Information plc v Michael Gerson (Finance) Ltd plc [2000] 4 All ER 734 (CA) 737 (Robert Walker LJ), reversed without impact on the point just made: [2002] UKHL 13, [2003] 1 AC 368. The new accounting standards (as of January 2019) treat all leases as the same for accounting purposes, requiring all lessees of leases of at least one year to recognise assets and liabilities unless the asset is of low value: International Financial Reporting Standards (IFRS) 16 Leases < https://www.ifrs.org/issued-standards/list-ofstandards/ifrs-16-leases/> accessed $27^{\text {th }}$ September 2018.

${ }^{14}$ Goode on Commercial Law (5th edn, London, LexisNexis Butterworths, 2016) para 22.05.

${ }^{15}$ Bridge et al (n 11) para 13-004, citing HMRC, CA23810-PMA: Long funding lease: lessees; Barclays Mercantile Business Finance Ltd v Mawson [2004] UKHL 51, [2005] 1 AC 684.

${ }^{16}$ Armour v Thyssen Edelstahlwerke AG [1991] 2 AC 339 (HL). For an academic argument (now of historic interest) that a contract of sale purporting to retain title until all liabilities due under any other contracts are discharged creates a security interest, see W Goodhart, 'Clough Mill Ltd v Martin - A Comeback for Romalpa' (1986) 49 MLR 96.
} 
which the two types of interests can be seen as similar.

Title-based financing interests and security interests are similar in at least two aspects. First, they perform a similar function as each enables the creditor/financier to resort to an asset $^{17}$ in order to discharge the ("secured") obligation prior to other creditors of the debtor, whilst also facilitating the debtor's use of the asset. ${ }^{18}$ Secondly, title-based interests can be seen as non-possessory interests, which are similar to a legal mortgage in the sense that the financier holds title but not possession.

However, it is clear that the courts do not regard these similarities as normatively significant, as will be shown immediately below. As to the similarity of function, the courts have consistently refused to treat a transaction as secured borrowing simply because the right which the creditor retains is intended to function and in fact functions economically as security. ${ }^{19}$ Instead, in determining the nature of the transaction, the courts aim to find the "substance of the transaction" 20 by reference to the nature of the obligations between the parties, as objectively manifested in the agreement ${ }^{21}$, rather than the purpose of the transaction itself. ${ }^{22}$ For example, parties to a contract expressed as a sale of debts may agree that the seller of the debts is under a duty to pay the buyer any shortfall in payment arising when the buyer realises the value of the assets by collecting the debts. ${ }^{23}$ In such cases, the courts determine the character of the transaction as a sale, based on the wording of the agreement, including the labels that the parties use, unless the agreement contains obligations which are inconsistent with a sale. ${ }^{24}$

As to the second common feature, the courts have implicitly denied its relevance and instead have focused on the difference in the way the two interests are created. In the case of a security interest, the person who has or will obtain title to the asset grants (confers) a new

\footnotetext{
17 The term "resort to an asset" is not commonly used in relation to title-based financing interests but it is should be understood in this context to mean the power that the owner has to re-possess its asset, including in insolvency of the possessor.

${ }^{18}$ Note, too, that courts have an inherent equitable jurisdiction to give relief against forfeiture (On Demand Information plc v Michael Gerson (Finance) plc [2003] 1 AC 368) which is said to be indicative of a security character of the interest: Shiloh Spinners Ltd v Harding [1973] AC 691; Beale et al (n 3) para 7.04.

${ }^{19}$ Welsh Development Agency v Export Finance Co [1992] BCC 270 (CA) 300 (Staughton LJ).

${ }^{20}$ See Re George Inglefield [1933] Ch 1, 26-8 (Romer LJ); Lloyds \& Scottish Finance Ltd v Cyril Lord Carpets Sales Ltd (1979) [1992] BCLC 609; Re Curtain Dream plc [1990] BCLC 925; Welsh Development Agency v Export Finance Co Ltd [1992] BCC 270; Orion Finance Ltd v Crown Financial Management Ltd [1996] 2 BCLC 78. See also L Gullifer, 'Quasi-security interests: functionalism and the incidents of security' in I Davies (ed), Issues in International Commercial Law (Aldershot, Ashgate Publishing, 2005); A Berg 'Recharacterisation after Enron' [2003] Journal of Business Law 205.

${ }^{21}$ If a document does not manifest the real intentions of the parties, it is regarded as a sham and as such it has no effect between the parties or against third parties although an innocent third party may be able to argue that a party to a sham document is estopped from relying on the sham transaction: Snook $v$ London and West Riding Investments Ltd [1967] 2 QB 786 (CA), and see Midland Bank plc v Wyatt [1995] 1 FLR 696, 699 (Young QC sitting as a deputy High Court judge).

${ }^{22}$ See Helby v Matthews [1895] AC 471 (HL) 475 (Lord Herschell LC): ‘. ...the substance of the transaction evidenced by the agreement must be looked at, and not its mere words.... But the substance must, of course, be ascertained by a consideration of the rights and obligations of the parties, to be derived from a consideration of the whole of the agreement.'

${ }^{23}$ See Lloyds \& Scottish Finance Ltd v Cyril Lord Carpets Sales Ltd [1992] BCLC 609 (HL) (there was a sale of debts even thought the buyer had a recourse against the seller for a shortfall); Welsh Development Agency $v$ Export Finance Co [1992] BCC 270 (CA) 279-280 (Dillon LJ).

${ }^{24}$ See Orion Finance Ltd v Crown Financial Management Ltd (No 1) [1996] 2 BCLC 78. This assumes the document is not a sham: see note 21 above.
} 
proprietary interest in favour of the creditor (the charge ${ }^{25}$, the equitable mortgage ${ }^{26}$ and the pledge ${ }^{27}$ ) or conveys title to the creditor for the purposes of security (the mortgage ${ }^{28}$ ). By contrast, title-based financing interests are created by retention of title by the creditor: ${ }^{29}$ the property right is not conferred upon the creditor but stems from a proprietary entitlement to the asset which the creditor already held. Even in the case of a sale and lease-back or buy-back, where the debtor first transfers title to the asset to the creditor, the proprietary interest which the creditor holds in the asset is created not by a grant by the debtor but by withholding the passage of title.

The contrast between a grant and a retention of a proprietary interest is at the heart of the distinction between security interests and title-based financing interests. This means that the courts recognise the proprietary effect of a transaction depending on whether they find that a proprietary interest was retained or granted. The way a proprietary interest arises does not necessarily define its nature. In the absence of a judicial guidance, it is possible to argue that even though the title-based financing interests are different from security interests, this does not mean that they are necessarily the same as simple ownership.

\section{TITLE-BASED FINANCING INTERESTS: SIMPLE OWNERSHIP OR A NEW TYPE OF PROPERTY RIGHT?}

It is important to know whether the proprietary nature of title-based financing interests amounts simply to ownership, or a new type of property right, in order to know whether any of the concerns that underpin the numerus clausus principle apply to them. There are two main arguments which support the view that title-based financing interests amount to simple ownership. One is that they are created as retained ownership, and the law gives effect to that intention by treating them like ownership. Another is that the courts have consistently distinguished them from security interests, emphasising the conceptual divide under English law between security interests and absolute interests ${ }^{30}$, the latter being ownership or possession in relation to personal property. ${ }^{31}$ The merits of the first argument are discussed below. The second argument was dealt with in the section above $\mathrm{e}^{32}$, where it was seen that the recognition

\footnotetext{
${ }^{25}$ Carreras Rothmans Ltd v Freeman Mathews Treasure Ltd [1985] Ch 207, 227 (Peter Gibson J); Re Bank of Credit and Commerce International SA (in liquidation) (No 8) [1998] AC 214 (HL) 226 (Hoffmann LJ) and Bond Worth [1980] Ch 228, 250 (Slade J) (drawing a distinction between a grant of a charge and conveyance in mortgage).

${ }^{26}$ Beale et al (n 3) paras 6.08-6.11.

${ }^{27}$ See e.g. Coggs v Bernard (1703) 2 Ld Raym 909, 916; 92 ER 107, 112 (Holt CJ); Donald v Suckling (1866) LR 1 QB 585, 595 (Shee J), 606 (Mellor J), 614 (Blackburn J) referring to "special property" conferred on the possessor.

${ }^{28}$ Beale et al (n 3) para 6.05.

${ }^{29}$ McEntire v Crossley Bros [1895] AC 457 (HL) 470 (Lord Shand); Clough Mill Ltd v Martin [1985] 1 WLR

111 (CA) 123 (Oliver LJ) and 125 (Sir John Doldson MR); Armour v Thyssen Edelstahlwerke AG [1991] 2 AC 339 (HL) 353 (Lord Jauncey). See also L Gullifer (ed), Goode and Gullifer on Legal Problems of Credit and Security (London, Sweet \& Mawell, $6^{\text {th }}$ edn, 2017) para 1-31.

${ }^{30}$ Beale et al (n 3) para 4.01; S Worthington, Personal Property Law: Text, Cases and Materials, (Oxford, Hart Publishing, 2000) 57-8.

${ }^{31}$ Goode on Commercial Law (n 14) ch 2, particularly paras 2.20-7. See also W Blackstone, Commentaries on the Laws of England, vol II (reprint edn, Chicago, University of Chicago Press, 1979) referring to things in possession as divided into "an absolute and a qualified property", the latter being pledge and bailment (at 3956).

${ }^{32}$ See section II.B above.
} 
of the distinction between security interests and title-based financing interests does not preclude us from saying that retained ownership is in fact a new type of property right.

\section{A. Simple ownership - the intention to retain ownership}

When A enters into an agreement with B for sale of an asset on retention-of-title terms, hirepurchase or lease, the proprietary effect that the parties aim to achieve is that $\mathrm{A}$ is to remain the owner subject to certain terms, e.g. performance of an obligation by B, while B obtains possession of the asset. For A to be able to contract on retention-of-title terms, A must already own the asset, even if for a short period and even if the asset was acquired from a third party specifically so that A could enter into a title-based transaction with B. ${ }^{33}$ Moreover, A can only retain the interest that she has. For example, an absolute owner of goods cannot retain only equitable ownership because it is not the case that an absolute ownership is a composite interest comprising legal and equitable ownership. ${ }^{34}$ For this reason, a purported retention of equitable ownership will amount to creation of a charge. ${ }^{35}$

Since A's intention is to retain what A already has, it can be said that by giving effect to a retention-of-title clause the law simply gives effect to that intention by recognising A's proprietary right after the transaction as the same right (i.e. ownership) prior to the dealing with B. The courts have made it clear that it does not matter what purpose or motive A might have in retaining the ownership. For example, the fact that A chooses to retain ownership for the purpose of securing B's obligation to pay, will not of itself preclude the effectiveness of the clause. $^{36}$

\section{B. Title-based financing interests differentiated from ownership}

The legal position of a person who reserves title appears equivalent to that of a person who holds absolute title and who has not entered into any transaction as far as its strength against third parties is concerned. ${ }^{37}$ After all, one could simply say that person retains ownership. The simplicity of this point betrays its importance. It is sometimes raised in the reform debate as the reason why there is no perceived need to regulate title-based interests (by e.g. requiring

\footnotetext{
${ }^{33}$ This is so generally with (finance) leases and hire-purchase agreements, which involve the financier purchasing asset from the supplier.

${ }^{34}$ Westdeutsche Landesbank Girozentrale v Islington LBC [1996] AC 669 (HL).

${ }^{35}$ Re Bond Worth [1980] Ch 228.

${ }^{36}$ See e.g. Welsh Development Agency v Export Finance Co [1992] BCC 270 (CA) 273 (Dillon LJ) (indicating that factoring of debts or invoice discounting, which are forms of outright assignment are legitimate ways to raise finance, and it is not necessary to use a charge). An analogous point can be made about title-based financing transactions. See also McEntire v Crossley Bros [1895] AC 457 (HL) 465-466 (Lord Herschell LC) and J H Dalhuisen, Security and Ownership Based Funding Techniques (2) [1998] European Business Law Review 118,123 . $C f$ the position in Germany in the $19^{\text {th }}$ century where retention of title clauses seemed to have become common because buyers were not able to easily borrow money from lending institutions: see $\mathrm{R}$ Pennington, 'Retention of Title to the Sale of Goods under European Law' (1978) 27 International \& Comparative Law Quarterly 277. In modern times in England, a person who seeks finance is free to choose sale credit (from e.g. a supplier) over loan credit (from e.g. a bank) and will make the decision based on the usual factors such as cost of credit transaction, ease of transaction. It is not clear to what extent personal or institutional biases play a role, for example whether a debtor takes sale credit as a matter of habit.

${ }^{37}$ Each form of title-based transactions gives rise to rights and powers, duties and liabilities between the parties. For example, a contract of sale of an asset with a retention-of-title clause gives rise to a (self-executing) duty on the seller to transfer property in the asset upon the fulfillment of the contractual condition.
} 
registration and/or recharacterising such interests as security interests); ownership is thought to be beyond regulatory concerns.

What follows is an argument that the protection afforded by a title-based interest on its holder vis-à-vis third parties is weaker than that offered by absolute title (ownership). This is so: (i) as a matter of policy, because the public aspects of private legal relations relating to things are different in the case of title-based interests as compared to absolute interests; and (ii) as a matter of principle under the current law, because there are instances where title-based interest holders receive less protection of their interest compared to owners.

\section{(i) Policy}

An absolute owner does not need to be concerned with publicising her interest to third parties, at least in the case of assets that do not have registers in which ownership would be registrable. 38 The owner need not even be particuarly careful with the asset. For example, if an owner carelessly loses a gold watch, she does not cease to be any less protected and third parties do not become more worthy of protection if they take the asset. ${ }^{39}$ However, the law's response is different in the case of title-based financing interests because the owner has entrusted the possession of its object to a third party, and at the very least must be taken to have accepted the risk that the third party might deal with the asset, and that when they do an innocent party may require protection. The entrustment of possession is not a unique feature of title-based financing interests but for current purposes it need not be; it simply shows that the public aspects of private legal relations relating to things are different in the case of title-based interests compared to absolute interests.

\section{(ii) As a matter of principle under current law}

The strength of a property right can be measured by considering the extent to which it empowers the right-holder to exclude various third parties from the asset. This is based on a view that the distinctiveness of property rights lies not in A's liberty to use an asset but in the duty, owed to A, that it imposes on the rest of the world. ${ }^{40}$ For the purposes of this chapter, it is convenient to separate different categories of third parties: (i) strangers who interfere with the possession of the physical asset; (ii) disponees to whom the possessor ${ }^{41}$ purports to sell the asset, give a security interest in the asset, or with whom it enters into a title-based arrangement; and (iii) insolvency officers (an administrator, a liquidator or a trustee in bankruptcy) of the possessor.

\footnotetext{
${ }^{38}$ The obvious example is the land register.

${ }^{39}$ See Farquharson Brothers \& Co v King \& Co [1902] AC 325 (HL) 332 (Earl of Halsbury LC).

${ }^{40} \mathrm{~J}$ Penner, The Idea of Property in Law (Oxford, Clarendon Press) 71; T Merrill, 'Property and the Right to Exclude' 77 Nebraska Law Review 730; H Smith, 'Exclusion versus Governance: Two Strategies for Delineating Property Rights' 31 The Journal of Legal Studies S453; H Smith, 'Property as The Law of Things' 125 Harvard Law Review 1691; S Douglas and B McFarlane, 'Defining Property Rights', in: J Penner and H Smith (eds), Philosophical Foundations of Property Law (Oxford, Oxford University Press, 2013) 219. The terminology in the text closely mirrors the last-mentioned work.

${ }^{41}$ The term "possessor" is used here to mean the person who entered into the title-based financing arrangement, and it is assumed for simplicity that they remain in possession of the asset.
} 


\section{a. Enforceability against wrongdoers through the tort of conversion}

As a general rule, when a third party interferes with a physical asset, the possessor or a person with an immediate right to possess can sue the wrongdoer for conversion to recover damages, ${ }^{42}$ calculated by reference to the full value of the asset ${ }^{43}$ at the time of the conversion. It is debated whether damages for the tort of conversion (as well as other torts and breach of contract) are meant to provide a substitute for, and so to vindicate, the right that was infringed, ${ }^{44}$ or to compensate the actual loss suffered, which involves taking into account the rules on causation, remoteness and mitigation. The latter is the mainstream view. ${ }^{45}$ In the context of the tort of conversion, authorities suggest that damages are awarded for the loss suffered ${ }^{46}$, and the consideration of causation, remoteness and mitigation is relevant. ${ }^{47}$

When goods are bailed, damages are not generally limited by reference to the value of the claimant's interest in the converted asset. ${ }^{48}$ For example, a pawnbroker may recover from a third party wrongdoer damages that amount to the full value of the converted goods, although this is subject to a duty to account to the pawnor for the surplus. ${ }^{49}$ This would suggest that a title-based interest holder should be able to recover the full value of the asset when, e.g., the possessor is permanently deprived of the asset by third party wrongdoer. But this is not so. Cases involving hire-purchase agreements suggest that the financier is only able to recover damages that amount to the financial value of its interest.

In Wickham Holdings v Brooke House Motors Ltd ${ }^{50}$ the financier (the "owner") sought damages for the entire value of a car, which had been let on hire-purchase and had subsequently been converted by a third party. The financier claimed damages without taking into account payments already received from the debtor. The Court of Appeal held that the financier could not recover more than the damages for its actual loss and required a deduction to be made for

\footnotetext{
42 Other remedies for conversion are delivery up of the asset and injunction: Torts (Interference with Goods) Act 1977, s 3 .

${ }^{43}$ Solloway v McLaughlin [1938] AC 247 (PC); BBMB Finance (Hong Kong) Ltd v ED Holdings Ltd [1990] 1 WLR 409 (PC) 412-3 (Lord Templeman); Malkins Nominees Ltd v Société Financière Mirelis SA [2004] EWHC 2641 (Ch) [34] (Laddie J); McGregor on Damages (20th edn, London, Sweet \& Maxwell, 2017) para 36.011.

${ }^{44}$ R Stevens, Torts and Rights (Oxford, Oxford University Press, 2007); R Stevens, 'Damages and the Right to Performance: A Golden Victory or Not?' in J W Nyers et al (eds), Exploring Contract Law (Oxford, Hart Publishing, 2009) 171.

${ }^{45}$ See e.g. McGregor on Damages (n 43); and R Hickey, 'Defending Property: Self-Help Remedies, The Use of Force and the Concept of a Property Right', chapter XX in this volume. For arguments against the substitutive damages thesis, see A Burrows, 'Damages and Rights' in D Nolan and A Robertson (eds), Rights in Private Law (Oxford, Hart Publishing, 2012) 275.

${ }^{46}$ VFS Financial Services (UK) Ltd v Euro Auctions (UK) Ltd [2007] EWHC 1492 [94] and [102] (Richard Seymour QC).

${ }^{47}$ Kuwait Airways Corporation v Iraqi Airways Co (Nos 4 \& 5) [2002] UKHL 19, [2002] 2 AC 883. For the relevance of mitigation, see Uzinterimpex JSC v Standard Bank Ltd [2008] EWCA Civ 819, [2008] 2 Lloyds Rep 453, 469-470 (Moore-Bick LJ); regarding remoteness, see Kuwait Airways Corporation v Iraqi Airways Co (Nos 4 \& 5) [2002] UKHL 19, [2002] 2 AC 883. See also generally S Green and J Randall, The Tort of Conversion (Oxford, Hart Publishing, 2009) 191-201.

${ }^{48}$ The Winkfield [1902] P 42 (CA); Green and Randall (n 47) 172.

${ }^{49}$ Swire v Leach (1865) 18 CB (NS) 479, 492; 141 ER 531, 536 (Erle CJ). Between the bailor and bailee the party who recovers must account to the other: The Winkfield [1902] P 42 (CA) 60-1 (Collins MR) (duty to account by the recovering bailee), O'Sullivan $v$ Williams [1992] 3 All ER 385 (duty to account by the bailor). ${ }^{50}$ [1967] 1 WLR 295 (CA). See also Belvoir Finance Co Ltd v Stapylton [1971] 1 QB 210 (CA) (note that the hire-purchase contracts in this case were illegal but since the contracts were fully executed the claimant financier obtained property in the lorry and could therefore sue in conversion). Wickham was followed in VFS Financial Services (UK) Ltd v Euro Auctions (UK) Ltd [2007] EWHC 1492, especially [102], [104] (Richard Seymour QC).
} 
payments already made. ${ }^{51}$ The rule was explained in the following terms by Fox LJ in Chubb Cash v John Crilley:

The court regarded it unjust that, if the hire-purchase owner had only a limited interest in the goods (i.e., the outstanding instalments), he should recover their full value. The damage, therefore, was limited to the actual amount of the loss, that is to say the amount still outstanding under the hire-purchase agreement. ${ }^{52}$

In hire-purchase cases the actual loss recoverable by the financier is measured by reference to the amount that the financier is yet to be paid under the agreement. This is so even though the hire-purchase agreement does not confer on the financier any duty to pass property in the asset at the end of the hiring period to the hirer. Analogous reasoning can apply to the interest of the seller who retained ownership and a lessor in the context of asset finance.

One explanation of the difference between the pledge cases and hire-purchase cases is that a pledgee has a duty to account to the pledgor for any surplus (over the amount of the discharged secured obligation) inherent in the nature of the pledge, while in hire-purchase agreements there is nothing to oblige the title-interest holder to account to the hirer for the rentals paid. ${ }^{53}$

A second explanation, suggested here, starts from the premise that title-based interests differ from security interests. ${ }^{54}$ While security interests are dependent on the extent to which a secured obligation remains unperformed, ${ }^{55}$ title-based interests are not. Thus, a limitation of the title-based interest became necessary to prevent the title-based holder from benefiting unduly from its legally advantageous position and to preclude opportunistic behaviour. The limited interest referred to in Chubbs must mean a limited financial interest, determined by reference to the capital value of the retained asset in accordance with the terms of the agreement. This second explanation is meant to complement, rather than contradict the explanation referring to the duty to account.

On either view, it would seem reasonably clear that the measure of damages for conversion is more generous in the case of absolute interests than it is in the case of title-based financing interests.

\section{b. Enforceability against disponees - nemo dat and its exceptions}

A title-based financing interest held by $\mathrm{A}$ in goods possessed by B binds a third party disponee (C) because, unless A consents, $\mathrm{B}$ cannot pass to, or create in favour of, $\mathrm{C}$ a greater interest than $\mathrm{B}$ has (nemo dat). There are some statutory exceptions to this derivative title rule. However, as the discussion that follows shows, ${ }^{56}$ their scope of application is rather narrow, and displays an idiosyncratic nature, commensurate with their development as responses to specific concerns to protect certain innocent buyers. They all require that B should be in

\footnotetext{
51 [1967] 1 WLR 295 (CA) 299-300: Lord Denning MR said that the plaintiff finance company was "only entitled to what it had lost by the wrongful act of the defendants".

52 [1983] 1 WLR 599 (CA) 601.

${ }^{53}$ McGregor on Damages (n 43) para 38-065, noting that this point was made in an analogous case of a buyer, who has not paid the price for the goods, seeking to recover damages from the seller for reselling the goods to third party: in Chinery $v$ Viall (1860) $5 \mathrm{H} \& \mathrm{~N} 288$ the buyer was held able to recover the full value of the goods less the agreed price.

${ }^{54}$ See section II.B above.

${ }^{55}$ In Civilian and mixed jurisdictions, the dependence on the secured obligation is known as accessoriness (or accessority) of security rights.

${ }^{56}$ What follows is an abbreviated discussion of exceptions to nemo dat found in Raczynska (n 9) paras 2.102-

2.111 .
} 
possession of the goods with A's consent. ${ }^{57}$ While some exceptions initially developed to protect innocent buyers when goods were entrusted by an absolute owner to a professional seller for onward resale ${ }^{58}$, nowadays the circumstances in which an owner entrusts goods to another are probably more likely to occur instead under a title-based arrangement.

A seller supplying goods under a contract of sale with a retention of title clause may lose its title if C successfully raises a defence based on s 25 of the Sale of Goods Act 1979 (s 9 of the Factors Act 1889). For the defence to be available, a number of factors must be met. $\mathrm{C}$ must show that B was a "buyer", i.e. a person who agreed to buy goods, and that she was in possession of the goods, with A's consent, at the time of disposition to C. B must have been in possession of the goods under the contract of sale with the retention of title clause, not under another agreement. ${ }^{59}$ Where these requirements are fulfilled, the disposition to $\mathrm{C}$ has "the same effect as if the person making delivery or transfer were a mercantile agent in possession of the goods or documents of title with the consent of the owner". These words are not easy to understand but were eventually interpreted by the Court of Appeal in Newtons of Wembley Ltd $v$ Williams $^{60}$ as impliedly importing the requirements of s 2 of the Factors Act 1889. Thus, C can only raise the defence if the disposition was made in a manner in which it would have been made had the buyer been disposing in the ordinary course of business of a mercantile agent. ${ }^{61}$ This limitation of s 25 to buyers in the ordinary course of business was intended to protect A's ownership ${ }^{62}$ but its denial of protection to buyers not buying in the ordinary course of business is unfortunate and unjustified on any rational policy grounds. ${ }^{63}$ Where goods are supplied under a hire-purchase agreement, B's position somewhat resembles that of a buyer under a contract of sale with a retention of title clause. However, s 25 of the Sale of Goods Act 1979 does not apply, since B does not undertake an obligation to buy but merely has an option to purchase. Thus, she is neither a person who "bought or agreed to buy" for the purposes of the section. ${ }^{64}$ This caused significant problems in practice as innocent buyers were exposed to the risk of acquiring goods subject to ownership of another, without knowing and without having an opportunity to inspect the seller's title. Eventually, a new statutory defence under Part III of the Hire Purchase Act 1964 was introduced. It is limited to purchasers who are innocent private purchasers of a motor vehicle. B must be in possession of the vehicle under the hire-purchase agreement at the time the vehicle is disposed of to $\mathrm{C}$, so the hire-purchase agreement must be concluded before the vehicle is disposed of to $\mathrm{C} .{ }^{65}$ It is not entirely clear what constitutes "disposition" in s 27 of the 1964 Act but it seems to have been interpreted restrictively, as synonymous with "sale". For example, a transaction whereby B passed property in a vehicle to $\mathrm{C}$ in return for C's forbearance to sue B for part of a debt B owed to C does not amount to a

\footnotetext{
${ }^{57}$ A Tettenborn, 'Transfer of Chattels by Non-owners: Still and Open Question' (2018) 77 CLJ 151 calls for a recognition of a background rule of entrustment in the context of exceptions to nemo dat.

${ }^{58}$ Factors Act 1889 , ss 8 and 9.

${ }^{59}$ The practical difficulty of meeting the requirements of s 25 of the 1979 Act is illustrated by, e.g., Fadallah $v$ Pollak [2013] EWHC 3159 [55] (the defence failed as the buyer acquired possession prior to the agreement to buy).

60 [1965] 1 QB 560.

${ }^{61}$ Contrast the approach in Australia Langmead v Thyer Rubber Co Ltd [1947] SASR 29, 39 (Reed J) and New

Zealand Jeffcot $v$ Andrew Motors Ltd [1960] NZLR 721.

62 [1965] 1 QB 560, 564 (Sellers LJ).

${ }^{63}$ R Goode, 'Sale by Seller with Voidable Title' (1965) 115 Law Journal Newspaper 4. See also Forsyth International (UK) Ltd v Silver Shipping Co Ltd (The Saetta) [1994] 1 WLR 1334, 1351 (favouring contrary view to that in Newtons of Wembley but being bound by it).

${ }^{64}$ Helby v Matthews [1895] 2 QB 537; Belsize Motor Supply Co v Cox [1914] 1 KB 244; Modern Light Cars Ltd v Seals [1934] 1 KB 32, 43 (Roche J); United Dominions Trust (Commercial) Ltd v Parkway Motors Ltd [1955] 1 WLR 719.

${ }^{65}$ Kulkarni v Manor Credit (Davenham) Ltd [2010] EWCA Civ 69; [2012] 2 Lloyd's Rep 431.
} 
disposition on the basis that it would also not be a sale, ${ }^{66}$ and the court indicated there were no reasons to expand this protection. ${ }^{67}$

In some circumstances, $\mathrm{C}$ might look to rely on the "seller in possession" defence under s 24 of the Sale of Goods Act 1979 (s 8 of the Factors Act 1889). The defence might arise where B first sells the goods to A, who lets them back to B on a hire-purchase agreement. Unlike s 27 of the Hire Purchase Act 1964, it is not restricted to sales by B to C, and C need not be a "private purchaser". The likely challenge for C with s 24 is to show that B is a seller who "continues in possession". Contrary to previous thinking, ${ }^{68}$ it is not necessary that the seller must continue in possession as a seller ${ }^{69}$ which suggests that, upon taking the possession of the goods under a hire-purchase agreement and becoming a bailee, B constitutes a "seller in possession" for the purposes of s 24 .

A disposition of the leased goods by a lessee cannot, generally, deprive the lessor of its title to the goods. The "seller in possession" defence under s 24 of the Sale of Goods Act 1979 might, however, be raised where the lessor-to-be (A) first buys the goods from the lessee-tobe (B) and then A leases them back to B. Such lease-back transactions are not uncommon if B seeks to use the asset to raise finance. If B then sells the goods to a third party (C), the third party might raise a "seller in possession" defence, as discussed above in the context of hirepurchase agreements, so long as there is no break in B's possession between the sale from B to $\mathrm{A}$ and the second sale from B to $\mathrm{C}{ }^{70}$

Apart from the complexity of the picture, the obvious conclusion is that the current law gives the holder of a title-based financing interest less protection against third parties compared to an absolute owner. An owner who retained title in a title-based financing transaction will, however be protected as strongly as an absolute owner in cases where the innocent third party is a secured creditor. This is a sensible rule insofar as it gives the title-based interest holder a strong position when the debtor has not paid much towards the capital value of the asset. However, once much of the capital value of the asset has been paid for by the debtor, the question arises whether the debtor should be able to deal with the asset unencumbered (e.g. by granting security interests in order to obtain further finance against the asset), at least to the extent that the asset has been paid for. There is ultimately a policy choice as to whether financing should be encouraged in this way, but if it should, it is worth considering how the law might need to adjust.

\section{c. Enforceability against insolvency officers}

\footnotetext{
${ }^{66}$ For authorities that exchange of property in return for a forbearance of debt (where no money is paid at all) is not a sale, see e.g. Simpson v Connolly [1953] 1 WLR 911, 915 (Finnemore J) (in relation to land but stating that the same principles are relevant as in the case of sale of chattels); Robshaw Bros Ltd v Mayer [1957] Ch 125, 129 (Upjohn J).

${ }^{67}$ VFS Financial Services Ltd v JF Plant Tyres Ltd [2013] EWHC 346 (QB) [2013] 1 WLR 2987 [18]-[19] (Judge Mackie QC); Royscott Trust v Burno Daken Ltd (unreported) 9 July 1993 (Astill J) cited in the relevant part in VFS Financial at [10]. See also Kulkarni v Manor Credit (Davenham) Ltd [2010] EWCA Civ 69; [2012] 2 Lloyd's Rep 431 [15]-[16].

${ }^{68}$ Staffs Motor Guarantee Ltd v British Wagon Co Ltd [1934] 2 KB 305, Eastern Distributors Ltd v Goldring [1957] 2 QB 600.

${ }^{69}$ Pacific Motor Auctions Pty Ltd v Motor Credits (Hire Finance) Ltd [1965] AC 867 (PC), followed by the Court of Appeal in England: Worcester Works Finance Ltd v Cooden Engineering Co Ltd [1972] 1 QB 210 (CA) 217 (Lord Denning MR).

${ }^{70}$ Pacific Motor Auctions Pty Ltd v Motor Credits (Hire Finance) Ltd [1965] AC 867 (PC). See also Mitchell v Jones (1905) 24 NZLR 932.
} 
As against the insolvency officers of the possessor, title-based interests are enforceable in the same way as absolute ownership: anyone holding such interests may take the asset outside insolvency of the possessor. ${ }^{71}$ To that extent, as a matter of current law they are as robust as absolute interests.

However, there are cases where the owner cannot simply take what is his. In Re Piggin ${ }^{72}$ Carey Evans $J$ held that a clause in a hire-purchase agreement which gave the owner a right to terminate the agreement if the hirer or other counterparty were to go into insolvency was not enforceable. The owner had to accept what was owing to it under the agreement, and accept that the trustee in bankrupcty was able to exercise the option to purchase, which meant that the owner lost its ownership under terms other than those agreed. There were two reasons given for this decision. One was that the trustee in bankruptcy should take the rights and powers of the hirer for the benefit of the the hirer's creditors since the hirer acquired them for valuable consideration. The second reason was based on the equitable jurisdiction against forfeiture, which prevented the hirer from forfeiting the benefit of the hire-purchase agreement. Whilst the reasons for the decision have been doubted ${ }^{73}$, the decision has not been overruled and the outcome has its proponents. ${ }^{74}$ This suggests that it is at the very least arguable that in some circumstances an owner of an asset under a hire-purchase agreement may lose its ownership whilst an absolute owner would not.

The above discussion has shown that, under the current law, whilst title-based interests are protected in broadly the same way as absolute ownership, there are nonetheless circumstances where title-based interests will not be protected as strongly against third parties as absolute ownership. This is consistent with a policy recognising that the public aspects of private legal relations relating to things are different in the case of title-based interests compared to absolute interests.

\section{THE WAYS FORWARD?}

In many jurisdictions across the world title-based financing interests and security interests are treated in the same way, in the sense that a uniform set of rules governs priority conflicts, title transfers, opposability against execution creditors, and the effect of the interest in insolvency. They are treated in the same way because they perform the same function; the location of title is not decisive. ${ }^{75}$ Thus, a supplier of goods purporting to retain title does not retain title to an asset; instead, the law recognises the parties' intention to be that the supplier (the creditor) is to hold an interest in property for the purposes of security while the buyer or hirer of the goods

\footnotetext{
${ }^{71}$ For an order of claims in liquidation, bankruptcy or administration, see Re Nortel Companies; Bloom v Pensions Regulator [2013] UKSC 52 [39]-[40] (Lord Neuberger); Lehman Brothers International (Europe) (In Administration) [2015] EWCA Civ 485; [2015] BCC 431. The transactions, which give rise to the claims made are subject to the claw-back rules in insolvency law: see Insolvency Act 1986, ss 238, 339 (transactions at an undervalue) and ss 239, 340 (preferences), both sets of provisions juncto ss 240, 341 of the 1986 Act, and ss 423-425 of the 1986 Act (defrauding creditors).

72 (1962) 112 LJ 424.

${ }^{73}$ F Oditah F and A Zacaroli, 'Chattel Leases and Insolvency' [1997] Company Financial and Insolvency Law Review 29, favouring the decision in Roe on the demise of Hunter v Galliers (1787) 2 TR 133, 100 ER 72.

${ }^{74}$ This is based on the view that the hirer's option is a valuable asset, making the hirer's interest more than contractual: F Oditah, 'Assets and the Treatment of Claims in Insolvency' (1992) 108 Law Quarterly Review 459, 483-5.

75 Title has even more diminished role in the context of sale of goods under Article 2 UCC, see generally W L Tabac, 'The Unbearable Lightness of Title Under the Uniform Commercial Code' (1991) 50 Maryland Law Review 408; H Kripke, 'The Principles Underlying the Drafting of the Uniform Commercial Code' [1962] University of Illinois Law Forum 321, 328.
} 
(the debtor) obtains possession of the asset. ${ }^{76}$ That the supplier's interest is a security interest is made explicit in the Uniofrm Commercial Code (UCC) ${ }^{77}$ and is referred to as recharacterisation of the transaction. ${ }^{78}$

The functional approach was first adopted in Article 9 UCC, and then in various Personal Property Security Acts (PPSA's). ${ }^{79}$ In England and Wales, a wholesale reform along those lines was proposed by the Law Commission in $2004^{80}$ but the final recommendations, which, owing to time constraints, were more limited, ${ }^{81}$ were not enacted in the Companies Act 2006. The need and shape of further reform of the English law of secured transactions continue to be debated. ${ }^{82}$

There are two key arguments in favour of treating title-based financing interests in the same way as security interests. ${ }^{83}$ The first is that the forms of transactions are similar and should be treated alike. The premise is that a multiplicity of proprietary interests, where each interest is governed by its own different rules, makes the law unduly complex. Simplification of the rules based on function is a means to achieve this. Against this, it could be said that characterisation of transactions based on their economic function goes against the traditional and current approach of English law, as set out above. ${ }^{84}$ Conceptually, the functional approach is underpinned by a legal realist idea, propounded by the Chief Reporter for the UCC, Karl Llewellyn, that abstract concepts (such as title) cannot serve as a basis for resolving commercial disputes ${ }^{85}$ because, as another legal realist put it, they masquerade "in the cloak of legal logic" policy preferences that ought to be made explicit. ${ }^{86}$ On the continent, including in the UK, legal realism has much less traction. Concepts are important in achieving justice in like cases because of their invariance to context. ${ }^{87}$ They also help us keep track of the significance of legal changes in legal doctrines. ${ }^{88}$ Additionally, as Gullifer noted, it is no more logically necessary to distinguish between title-based financing interests and absolute

\footnotetext{
${ }^{76}$ See UCC $\$ 9-109(a)(1)$ : 'any transaction, regardless of its form, that creates a security interest in personal property or fixtures by contract'. See also, e.g., Saskatchewan PPSA 1993, s 3(1)(a); New Zealand PPSA 1999 , s 17(1)(a) and the Australian PPSA 2009, s 12(1).

${ }^{77}$ See UCC \$1-201(35): 'The retention or reservation of title by a seller of goods notwithstanding shipment or delivery to the buyer ... is limited in effect to a reservation of a "security interest".'

${ }^{78}$ M Bridge, 'Secured Credit Legislation: Functionalism or Transactional Co-Existence' in S V Bazinas and O Akseli (eds) International and Comparative Secured Transactions Law Essays in Honour of Roderick A Macdonald (Oxford, Hart Publishing, 2017) 1, 18.

${ }^{79}$ Personal Property Security Acts in all Canadian provinces except Québec, which did not follow Article 9 UCC when promulgating its new Civil Code; New Zealand PPSA 1999; Australian PPSA 2009 (Cth); also in other jurisdictions, e.g. Malawi.

${ }^{80}$ Law Commission, Company Security Interests: A Consultative Report (Law Com CP 176, 2004); Law Commission, Registration of Security Interests: Company Charges and Property other than Land (Law Com CP 164, 2002).

${ }^{81}$ Law Commission, Company Security Interests: Final Report (Law Com No 296, 2005).

${ }^{82}$ See the work of the Secured Transactions Law Reform Project (see n 1) and the City of London Law Society Financial Law Committee (see n 2). See also L Gullifer and O Akseli, Secured Transactions Law Reform. Principles, Policies and Practice (Oxford, Hart Publishing, 2016), particularly ch 12 therein (L Gullifer and M Raczynska, 'The English Law of Personal Property Security: Under-reformed?').

${ }^{83}$ See Gullifer (n 20); Attorney-General's Department, Review of Personal Property Security Act 2009: Final Report (2015) paras 4.1-3 (review of the PPSA in Australia).

${ }^{84}$ See section II.B above.

${ }^{85}$ See K N Llewellyn, 'Through Title to Contract and a Bit Beyond' (1938) 15 New York University Law Quarterly Review 159.

${ }^{86}$ F Cohen, 'Transcendental Nonsense and the Functional Approach' (1935) Columbia Law Review 809.

${ }^{87}$ For a discussion of the importance in property law of standards with a relatively high degree of invariance to context, see H Smith, 'Emergent Property' in J Penner and H Smith (eds), Philosophical Foundations of Property Law (Oxford, Oxford University Press, 2013) 320.

${ }^{88}$ J Waldron, 'Transcendental Nonsense and the System in the Law' (2000) 100 Columbia Law Review 16.
} 
ownership than it is to distinguish between security interests and title-based financing interests. ${ }^{89}$ The choice must be based on policy. ${ }^{90}$

As argued earlier, the question is whether title-based financing interests should protect a public goal. If title-based financing is to be encouraged as, e.g., an alternative to loan finance, whilst protecting an efficient use of resources, it would be necessary to recognise that the debtor (buyer, hirer, lessee) acquires, to the extent that the price or rent for the asset has been paid, a sufficient interest in the asset which they can use to e.g. raise further capital, or which can be used to the satisfaction of execution creditors. It is unlikely that financiers would perceive this as a negative development if as a result, the demand for such form of finance were to increase (and this is likely). A drastically different way to try to increase the proliferation of title-based finance interests would be to strengthen their proprietary protection, e.g., by giving full damages in the case of conversion. This option, however, might be perceived as less attractive by those seeking title-based finance, as their own interest would be less protected in case of an interference by a third party with the asset.

The second argument in favour of treating title-based finance interests and security interests similarly is that both forms of transactions share a common need for publicity. This argument used to be driven primarily by the desire to do away with the impression of false wealth posed by all non-possessory interests. ${ }^{91}$ Now, it is better seen as driven by the desire to lower the costs of due diligence, since a third party seeking to deal with the debtor would only need to check an (online) register in the first instance. The argument supports registration of both forms of transactions, but it does not necessarily support the view that both security interests and title-based financing interests should be treated in the same way for all other purposes. $^{92}$ In addition, it is necessary to consider whether lack of registration should necessarily invalidate the interest on the possessor's insolvency. ${ }^{93}$ Hire-purchase agreements and finance leases are already registrable in privately-operated registers (such as Experian, HPI Check), which could support public registration. However, such a reform would need to introduce some added value, e.g., by enabling third parties to rely on a register for the purposes of proving detrimental reliance, which is currently not possible. ${ }^{94}$

\section{$\underline{\text { V Conclusion }}$}

\footnotetext{
${ }^{89}$ Gullifer (n Error! Bookmark not defined.).

${ }^{90}$ See section III.B.i above.

${ }^{91}$ D Baird and T Jackson, 'Possession and Ownership: An Examination of the Scope of Article 9' (1983) 35 Stanford Law Review 175; R Goode, 'The Modernisation of Personal Property Security Law' [1984] 100 MLR 234. The premise of false wealth was critiqued because both security interests and title-based interests are so common that possession no longer indicates ownership and creditors are not misled: C Mooney, 'The Mystery and Myth of 'Ostensible Ownership' and Article 9 Filing: a Critique of Proposals to Extend Filing Requirements to Leases' (1988) 39 Alabama Law Review 683, 739-40.

92 It should be added that contracts of sale with retention-of-title clauses in the context of inventory, that is where goods supplied are e.g. on-sold, consumed or used in the process of manufacture give rise to separate considerations than asset finance, in particular they do not appear to give rise to the same concern about publicity as asset finance. See further the work of the Secured Transactions Law Reform Project, Case for Reform (April 2017) (n 1).

${ }^{93}$ As is the position in New Zealand, although there the lack of invalidation on insolvency applies across all interests, including security interests. It is said to be underpinned by the policy against 'false wealth' or 'secret liens', premised on the idea that prospective creditors make lending decisions on the basis of the appearance of wealth and on the fact that once the debtor is insolvent, no prospective creditor is prejudiced by the false wealth, so there is no need to penalize an unregistered interest. This position fails to take into account execution creditors. See D Dugdale, 'The Proposed PPSA' [1998] New Zealand Law Journal 383.

${ }^{94}$ Moorgate Mercantile Co Ltd v Twitchings [1976] QB 225.
} 
One of the recurring tensions in property law is between contract freedom and private volition on one hand and social control on the other. ${ }^{95}$ To address this conflict, the law has adopted a simple principle, namely that it is generally not the case that a contract between A and B can impose a new duty or liability on a third party. This principle is said to underpin the rationality of the numerus clausus principle. ${ }^{96}$ The principle stipulates that there exists a fixed list of property rights and unless the content of a right already matches one on the list, it cannot be regarded as having a proprietary status. The principle is said to exist in English law ${ }^{97}$ although it is not without sceptics. ${ }^{98}$ Alongside various efficiency justifications, ${ }^{99}$ there are also those that have focused on explaining the internal content of the standard forms of property right. ${ }^{100}$

Of particular interest is a view, propounded by Davidson, that having a fixed list of property rights plays a regulatory role, as property law is used as a means of defining, controlling and regulating the public aspects of private legal relations with respect to things. ${ }^{101}$ There are two interesting aspects of this view that lead to valuable conclusions when dealing with title-based financing interests. One is that although standardisation is a stable, persistent feature of property law, ${ }^{102}$ the list of forms and their substance have always been dynamic, representing inevitable tradeoffs between the choices that a holder of a property interest might make with respect to that property, and the effects those choices have on others. ${ }^{103}$ This means that one should keep an open mind to change. Just because title-based financing interests emerged from the exercise of the owner's freedom to withhold passing of property under a contract, this does not mean that the title which the owner holds is the same as absolute ownership. Nor does it mean that it ought necessarily be conflated with another category of property right. But it is an encouragement to consider the tradeoff of choices which the holder makes with the effects of those choices on others. This leads to the second point, which is that one should consider the social aspect of title-based financing interests and consider the public goals which a particular type of property right should protect. ${ }^{104}$ If the idea is that title-based financing interests should be just an incidental exercise of the owner's freedom, nothing needs to be done. However, if these interests are thought to correspond to an existing or new public

\footnotetext{
${ }^{95}$ See e.g. R Epstein, 'Notice and Freedom of Contract in the Law of Servitudes' (1981-2) 55 Southern California Law Review 1353.

${ }^{96}$ B McFarlane, 'The Numerus Clausus Principle and Covenants Relating to Land' in S Bright (ed), Modern Studies in Property Law, vol 6 (Oxford, Hart Publishing, 2011) 311, 315.

${ }^{97}$ W Swadling, 'Property' in A Burrows (ed) Englihs Private Law (2nd edn, Oxford, Oxford University Press, 2007) paras 4.09 and 4.129. For an illustration of this aspect of numerus clausus in relation to land, see Keppel $v$ Bailey (1834) 2 My \& K 517, 536; 39 ER 1042, 1049 (Lord Brougham LC). See generally B Akkermans, The Principle of Numerus Clausus in European Property Law (PhD thesis, Maastricht University 2008) 473; N M Davidson, 'Standardization and Pluralism in Property Law' (2008) 61 Vanderbilt Law Review 1597, 1605.

${ }^{98}$ B Rudden, 'Economic Theory v Property Law: The Numerus Clausus Problem' in J Eekelaar and J Bell (eds) Oxford Essays in Jurisprudence: Third Series (Oxford, Clarendon Press, 1987) 239.

99 T Merrill and H Smith, 'Optimal Standardisation in the Law of Property: the Numerus Clausus Principle' (2000) 110 Yale Law Journal 1; H Hansmann and R Kraakman, 'Property, Contract, and Verification: the Numerus Clausus Problem and the Divisibility of Rights' (2002) 31 Journal of Legal Studies S373; Davidson (n 98) 1597; McFarlane (n 97) 311, 315.

${ }^{100}$ See e.g. H Dagan, 'The Craft of Property' (2003) 91 California Law Review 1517, 1558 and 1562 (arguing, broadly, that the patterns of social relationships map onto the property categories); D Lewinsohn-Zamir, 'The Objectivity of Well-Being and the Objectives of Property Law' (2003) 78 New York University Law Review 1669.

${ }^{101}$ Davidson (n 98) 1601. This is based on Bentham's approach to property as 'entirely the work of law': J Bentham, The Theory of Legislation, tr. by R Hildreth (2nd edn, London, Trübner, 1871) 111.

102 See H Smith, 'The Persistence of System in Property Law' (2015) 163 University of Pennsylvania Law Review 2055.

${ }^{103}$ See for example the discussion in ch XX of this volume in S Pascoe, 'Re-evaluating Recreational Easements - New Norms for the Twenty-First Century?'.

${ }^{104}$ Davidson (n 98) 1648, 1649.
} 
goal or social priority (e.g. financing the acquisition of assets other than through banks), there may well be a need for considering a new category or subsumption of title-based finance interest to an existing category of property right other than ownership.

This chapter sought to show that framing the balance between preserving parties' bargains and the effects those have on third parties through consecration of ownership as the basis of title-based financing arrangement is unsatisfactory. From the perspective of property law, title-based financing interests should be recognised as a new form of property right, created by the financier (or the seller) when retaining ownership. Whether this justifies a statutory reform of registration and streamlining of the rules applicable to various interests is a separate matter, which requires the resolution of practical concerns. 